\author{
Associate Professor Adriana AnaMaria DAVIDESCU,PhD \\ The Bucharest University of Economic Studies \\ Labour Market Policy Department \\ National Scientific Research Institute for Labour and Social Protection \\ E-mail: adrianaalexandru@yahoo.com \\ Professor Liviu Stelian BEGU, PhD \\ E-mail: liviu.begu@ csie.ase.ro \\ Teaching Assistant Simona Andreea APOSTU, PhD \\ The Bucharest University of Economic Studies
}

\title{
COULD FDI INFLOWS BE CONSIDERED A DRIVER OF THE ROMANIAN ECONOMIC CONVERGENCE TO EUROPEAN UNION AVERAGE? A GRANGER CAUSALITY ANALYSIS
}

\begin{abstract}
The paper aims to investigate the causality relationship between the FDI flows as \% of the official GDP and the Romanian convergence index towards the EU-average, using Granger causality tests. Using a VECM model, we examine the impact of FDI on the Romanian convergence index covering the period 2000-2013.

The obtained results support a unidirectional short-run and long-run Granger causality that runs only from the FDI flows to the convergence index. In the longrun a $1 \%$ increase of FDI flows would imply an estimated increase of almost $0.61 \%$ in the economic convergence index of Romania towards the EU-average.

The IRF and the variance decomposition from VECM indicate a short-run positive relationship between FDI flows and the convergence index. The analysis leads to the finding that on the short-run a $1 \%$ increase in FDI/GDP contributes to an increase in the convergence index to EU-average by $1 \%$ over the next eight quarters.
\end{abstract}

Keywords: real convergence, structural convergence, foreign direct investments, Granger causality, VECM model, Romania.

JEL Classification: F21, E22, R42

\section{Introduction}

In this paper, we study the relationship between the economic convergence and the FDI during the period 2000 and 2013, trying to find any form of evidence that FDI inflows can be considered a driver of the Romanian economic convergence to European Union average. Noteworthy to mention is the fact that as far as the autors are aware, this paper is the first in the literature, dealing with this topic, while most 
Adriana Anamaria Davidescu, Liviu Stelian Begu, Simona Andreea Apostu

causality studies performed until know (on the Romanian economy) try to link the economic development, measured by GDP (or other related indicators) with other socio economic indicators like: labor force indicators and education related indicators (Viasu, 2015).

It is of significant importance to assess how Romania attracts foreign investments even though it is not a member of the Euro zone, but it is a member state of the European Union. The notion of convergence that we use in this research study refers to both, the real convergence (also known as income convergence), and to the structural convergence (more exactly the convergence recorded at the level of the structure of the economy).

The chosen period for the analysis conducted in this paper offers the opportunity to grasp into the effects of the recent economic crisis on both the FDI flows attracted by Romania and also on the economic convergence.

We will develop further our research based on two main hypotheses, supported by many scholars involved in the study of both phenomena. The first hypothesis that we have included in the study supports the idea that FDI attracted by an economy bring significant benefits into that economy, increasing in this way its competitiveness. In other words, we can assert that there is a high probability that more FDI can be translated into higher convergence level.

The second hypothesis presented by researchers supports the idea that FDI are attracted mainly in developed economies, and therefore, there is a high probability that a higher convergence level will increase the attractiveness of an economy in the eyes of foreign investors.

Bearing in mind this two main underlying hypothesis we structure our paper in four sections, as follows: literature review and general framework, where we discuss both the topic of economic convergence and main aspects related to FDI, data and methodology, where we clearly present the data used in the current research and we describe step by step our methodological approach, the section of empirical results where we descriebe extensively the main findings of the paper and also try to bring forward their main policy implications and finally we conclude our work with a section of conclusions.

\section{Literature review and theoretical considerations}

As already stated from both the title and the abstract, the main goal of this research paper is to investigate the possibility that FDI inflows are a significant driver of the economic convergence, in terms of both real and structural convergence for the case of Romania. Thus, our interest lies in finding any form of quantitative evidence that the increase of FDI inflows can be seen as an engine driving the Romanian economic convergence. This topic is of crucial interest nowadays when in Romania there is an important debate in the public space regarding the benefits brought by the foreign capital versus the benefits brought by 
Could FDI Inflows Be Considered a Driver of the Romanian Economic

Convergence to European Union Average? A Granger Causality Analysis

the Romanian capital and the need of state's involvement in supporting these two types of capital.

Bearing the importance of the topic in mind we can summarize our entire approach into two main research questions, as follows:

1) To which extent the foreign direct investment could influence the Romanian convergence towards the EU-average?

2) Are the FDI inflows determinants of the Romanian economic convergence to EU-average?

In order to provide an objective quantitatively measurable answer to this two fundamental questions, the Granger causality analsys under the vector error correction model will be applied.

The disparities registered among different countries and between different regions and their implications, with a direct impact on the living standards, are, in the nowadays reality, one of the most important issues studied both at theoretical and empirical level. In these circumstances the subject of poorer countries which register a higher economical growth than the rich and developed countries has been an important topic for scholars, business representatives and also sometimes for government representatives. When talking about Europe, the subject has become increasingly important and interesting since the European Union decided to extend towards the ex communist east and to develop regional development policies.

Therefore, the year 2004 and the year 2007 are important milestones for the enlargement process of the European Union when 12 new member states were accepted. By doing so the European Union has increased significantly the economical disparities among member states (the regional disparities are also very important). However, it is noteworthy to mention, from the point of view of our research, that those two milestones might be regarded as important moments when new investments opportunities appeared for many companies interested by foreign investments. The ex communist countries, included in the European Union had and still have a significantly lower development level as their western counterparts but have, in these conditions, an important growth potential.

In a paper published in 2003, van de Coevering describes the real convergence as a process consisting of two main aspects: structural convergence and growth convergence. He describes the structural convergence as the process which depicts the tendency to increase the similarities between the business cycles into two different economies. The growth convergence represents the process which describes the tendency to equalize income level and development level of two different economies. The theoretical foundation of the concept of real convergence has raised a large debate in the literature and many hypotheses were formulated about it (Galor (1996)). 
What is worth mentioning regarding the concept of convergence at the European level is the convergence index calculated based on 16 variables by Deutsche Bank and also the study regarding the nominal and real convergence in the European Union, conducted by Miron, Dima and Paun (2009).

Also notable for this topic is the fact that one of the most important policies of the European Union intends to reduce the disparities registered today between different regions (the European Union has a regional policy with a significant impact at national level also). By helping these poorer countries to reach the economical development level of the western countries, this policy lowers the attractiveness of these countries for foreign investments in search of increased efficiency but, on the other hand, helps them create a solid foundation for attracting those foreign investments with a higher technology level.

Foreign direct investments have been regarded with great caution by governments until recent decades when the globalization process has intensified its development. Afterwards, these foreign direct investments were regarded as an important source for economic growth (Wei (1995), Balasubramanyam, Vudayagi. N., Salishu M. and Sapsford, David. (1996), de Mello (1997)), mainly in countries with lower development levels. However, the findings of the research studies support the idea that the linkages between the two phenomena are complex and their magnitude depends heavily on the studied country and also on the evaluated time period. Moreover, there are important studies arguing that the benefits brought to an economy by the foreign direct investments depend heavily on the initial economical and technological levels of the host country (Buckley et al. (2002). De Mello, in his study published in 1997, suggests that the productivity of the host country increases only if a certain level of the human capital was reached. Following the same directions Borensztein et al (1998) show that foreign direct investments are more productive than national investments only if a certain stock of human capital exists.

Noteworthy is the fact that foreign direct investments were not just considered a source of capital but also an important source for better management skills, better technological skills, better paid jobs and more competitive products (Johnson (1972)).

Also of significant importance for our research are the studies conducted by Goldberg (1972), Root and Ahmed (1979) and Culem (1998) who suggest that the economic growth is not just a result of the foreign direct investments but also one of the most important determinants of such investments.

The foreign direct investments were regarded by the governments of the ex communist countries as an important tool that could fuel the economical development of their economies. On the other hand, the multinational companies regarded this new territory as a very favorable location for new investments which lead to acquiring new markets. Therefore, the evolution of the flows of foreign direct investments during this convergence (Strat and Popovici, 2015) process in 
Could FDI Inflows Be Considered a Driver of the Romanian Economic

Convergence to European Union Average? A Granger Causality Analysis

the new member states of the European Union and the interdependencies between inflows of FDIs and economic convergence are topics that are continuously raising important debates. Following the same direction, an important topic emerging in the scientific literature, in the context of the regional approach proposed by the European Union is the study of the attractiveness of NUTS 2 and NUTS 3 administrative entities for foreign investors and its impact on convergence (among them)(Strat, 2014; Davidescu et al., 2017).

Regarding the real convergence, in a study published in 2008, Onen obtains interesting results when he studies the relationship between economic growth and foreign direct investments. He finds a negative impact of the economic growth on the net foreign direct investments for the cases of Turkey, China and USA. Diaz Vazquez concludes, in a research paper published in 2004 on the topics of regional convergence and foreign direct investments, that the economic convergence is harder to achieve because developed countries internalize better the benefits brought by foreign direct investments than developing countries.

Another important determinant (regarding the topic of convergence) of the foreign direct investment, identified by many scholars is the market size (BajoRubio, Oscar and Sosvilla-Rivero Simon (1994), Díaz Vázquez et al. (1996)). These results are in line with those obtained by Schneider and Frey, in a study published in 1985 and by Vijaykumar et al., in a study released in 2010.

After A. Smith published his work entitled The Wealth of Nations, a lot of researchers supported in their studies the idea that countries who open their economy to international commerce achieve a greater economic growth that those countries that develop closed economies. In the same line are the results reported by Basu et al. (2003), in a study where they use a panel of 23 developing countries. They report that between the foreign direct investment and the gross domestic product there is a bi-directional causal relationship, for countries with open economies and, on the other hand, for countries with closed economies, only the economic growth is the one attracting foreign direct investments.

Another important finding regarding this topic (income/growth convergence) is reported by Choi in a study released in 2004 where he argues that the disparities between income level and growth level for two economies tend to decrease while the flow of foreign direct investments between them increases.

Therefore, when we take the analysis at the level of the European Union we need to mention that the trade integration in the Union and also the synchronization of the business cycles with the Union's ones, increases the correlation of macroeconomic shocks and also diminishes the probability of occurrence of asymmetric shocks in the composing economies. The basic argument of such logic is represented by the assumption that an increase in the income of a country will drive automatically an increase in the income of the trade partner countries. Following this direction Frankel and Rose show, in a study released in 1998, that 
Adriana Anamaria Davidescu, Liviu Stelian Begu, Simona Andreea Apostu

adopting a common currency catalyzes the trade between the countries and also increases the correlation between business cycles from different countries (members of the common currency area). On the other hand, in a study published in 1991, Krugman argues that the trade integration might be a source for the occurrence of asymmetric shocks due to the higher economic specialization involved by such a process. More over, as some researchers have stated, foreign direct investments might have a negative impact on economies due to the fact that shocks might spread easier using the FDI as a channel.

Scholars have also found evidence that foreign direct investments have longer lasting effects on economies than trade has. Important in this regard is the study published by Jansen and Stockman (2004) who conduct their analysis on a sample of 12 countries for the period $1982-2001$.

It is also assumed that inward foreign direct investments towards the new member states of the European Union will increase the similarities of economical structure (industrial structure) in these countries to those existing in the rest of the Union (Barrios, Barry and Strobl (2002)).

Alexe I. and Tatomir C., in a research paper published in 2011, on a sample of five east European countries, search for evidence to support the idea that the process of economic convergence with the EU levels leads to higher inflows of foreign direct investment in an economy. Their analysis, performed for the period $2001-2010$, identifies a positive relationship between the two studied phenomena for the case of Bulgaria. On the contrary, for Hungary they report a divergent relationship between the analyzed indicators. Finally for Romania, Poland and the Czech Republic they do not report the existence of any correlation.

Summarizing this section and taking all this assumptions and findings into account we state once again that through the present study we try to evaluate the impact of the inflows of foreign direct investments on the Romanian economic convergence index's evolution towards the European Union average, using a Granger causality analysis.

\section{Data and methodology}

In order to investigate the relationship between FDI and the economic convergence index for the case of Romania, towards EU average we have used quarterly data covering the period 2000Q1-2013Q2. The foreign direct investment flows are expressed as percentage from GDP, while the economic convergence index is determined using two equal component indices: real convergence index and structural convergence index both expressed in $\%$.

The data has been seasonally adjusted using tramo seats method. The main sources for collecting the data are the quarterly databases of Eurostat and of the Internal Financial Statistics of International Monetary Fund. All the data were collected from the Eurostat database, except the FDI time series which was downloaded from the database of the International Monetary Fund. 
Could FDI Inflows Be Considered a Driver of the Romanian Economic Convergence to European Union Average? A Granger Causality Analysis

According to the FDI 2012 statistical survey methodology, based on the IMF Balance of Payments Manual, 5th edition (BPM5), the foreign direct investment is defined as a long-term investment relationship between a resident and a nonresident entity. The concept of foreign investment used in the IMF Balance of Payments, 5th edition, represents the base for the adopted definition of OCDE in the Manual Detailed Benchmark Definition of Foreign Direct Investment.

According to the Balance of Payments Manual-Financial Account, we have used as proxy variable for foreign direct investment: the direct investment abroad formed by equity capital, reinvested earnings and other capital.

The Romanian convergence index for conducting the comparison with the EU27 average is based on the research methodology proposed by the Group of Applied Economics (GEA) in the handbook for assessing the regional competitiveness of Romania and is presented extensively in Alexe and Tatomir (2011).

The real convergence index is obtained by weighted average of three indicators: $50 \%$ share of real labor productivity per person employed, 25\%-real GDP per capita and 25\%-real economic growth, as percentage of the EU average. All these indicators are computed as numbers between 0 and 100, expressing the distance against the EU average, 0 meaning no convergence with the European average and 100 meaning full convergence with the European average.

The structural convergence index is also obtained by weighted average of three indicators: highest share (70\%) is given to sectoral convergence index, $10 \%$ to economic openness degree and $20 \%$ to trade intensity indicator. A detailed description of the construction of this convergence index is presented in Alexe and Tatomir (2011).

In order to quantify the potential impact of the flows of foreign direct investments received by Romania on the economic convergence speed towards the European Union average we have employed the following econometrical techniques: non-stationarity tests (ADF and PP tests), Johansen co integration test, estimation of VECM models, Granger causality method and finally the short-run analyses of the impulse response function and variance decomposition.

For the case when both variables are integrated on the same order and they are also co integrated, the Granger causality test was performed under VECM (t-ratio of error correction term (ECT) for long-run and Wald test for short-run coefficients should be statistically significant). In order to identify such a relationship, the tratio of the ECT should also be negative and statistically significant and accompanied by a significant value for the $\mathrm{F}$ value of the model. Therefore, the significance of the error correction term signals the presence of the causality in at least one direction. 
Adriana Anamaria Davidescu, Liviu Stelian Begu, Simona Andreea Apostu

A step by step presentation of both Granger and Toda-Yamamoto causality methodologies is offered in the articles Davidescu and Dobre (2012) and Davidescu and Dobre (2013).

\section{Empirical results}

Romania reports a steady progress in the convergence process, but very fluctuating levels of the FDI inflows during the analyzed period ( between 2001 2010). The time series of the FDI inflows can be divided into three main periods. Until 2004 the evolution was very smooth and characterized by a very low positive trend. For the period $2004-2009$, the positive trend was still present but the evolution was affected by severe fluctuation, from quarter to quarter. During the last period, 2009 - 2013, the trend becomes negative. Moreover, the fluctuations tend to disappear in the second part of the period. As far as the time series of the convergence index is regarded, starting from 2005, the seasonal disparities tend to increase in magnitude.

Going further with the analysis of the interdependencies between the two quarterly series, it is relevant to mention that they have a common trend. Even though, the strength of the relationship is rather low (the value of the correlation coefficient is 0.37) it is important to mention that we have identified a positive relationship.

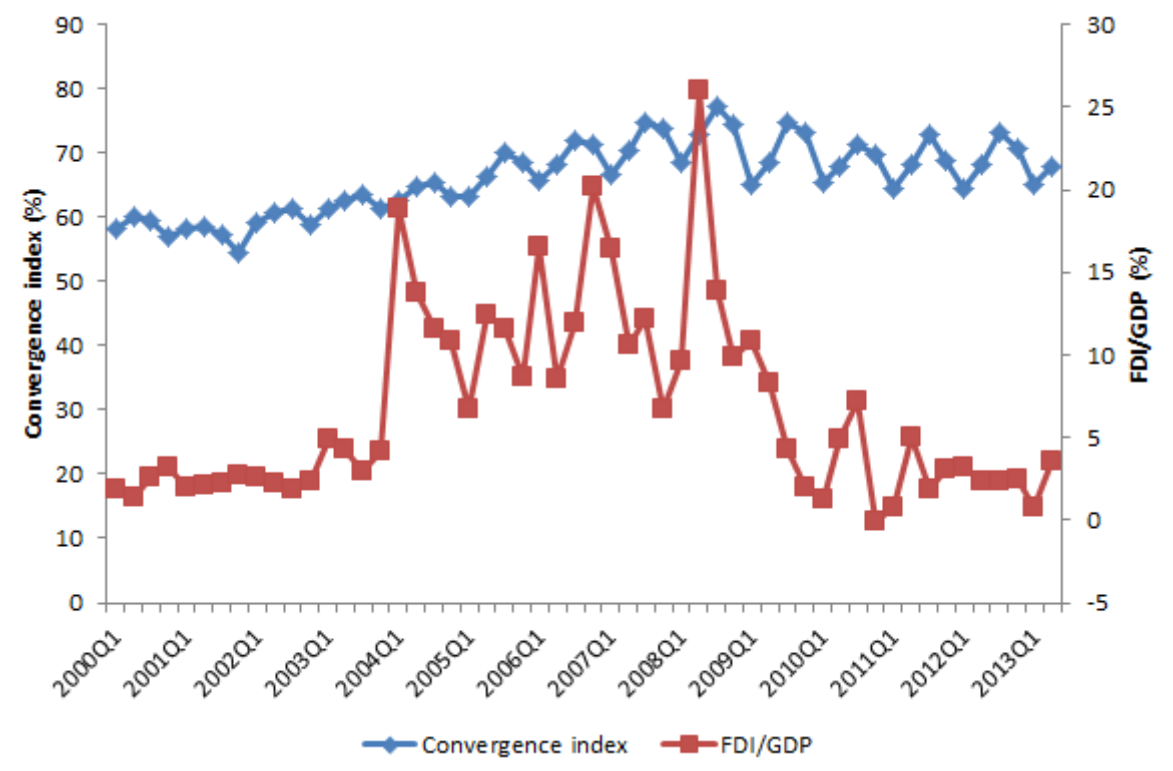

Figure 1. Economic convergence index vs. FDI flows/GDP in Romania over the period 2000-2013 
Could FDI Inflows Be Considered a Driver of the Romanian Economic Convergence to European Union Average? A Granger Causality Analysis

The first step, when investigating the interdependencies between two variables with the purpose of identifying any possible direction of causality between them, is to identify the level of integration of the two time series. Following the methodological approach proposed earlier in this paper we will employ in this activity the ADF and PP unit root tests. Noteworthy is that both tests revealed that the variables are non-stationary at their levels but stationary at their first differences, being therefore integrated of order one, I (1).

Due to the fact that both time series are integrated of the same order, I (1), we will proceed further with applying the Johansen and Juselius co integration procedure in order to investigate if there is a long run relationship between the convergence index and the FDI flows.

Prior to performing the co-integration test, we need to determine the optimal lag length estimating a VAR model using un-differenced data (variables in levels) and choosing the lag for which the residuals pass the diagnostic tests of nonautocorrelation, homoscedasticity and normality. Moreover, for the selected lag, the model needs to fulfill the stability condition. Since the total number of observations is only 54, we have used a maximum number of 4 lags, eliminating the serial autocorrelation of residuals. The optimal number of lags was chosen to be 3, according to LR, FPE, AIC and HQ criterions. The decision was also made bearing in mind to solve the problem of losing fundamental observations.

Using Pantula's (1989) principle, the empirical results suggest the choice of model 4 (with intercept and trend in the co integrating equation and no intercept in VAR) as the appropriate model. The results point out the existence of a unique co integrating relationship (a long run relationship) between the variables.

Due to the fact that a long run equilibrium relationship is found between convergence index and FDI flows, expressed as \% of GDP, a VECM model will be constructed to determine the direction of causality between the two variables. The empirical results are presented in table 1.

Table 1. The empirical results of VECM model

\begin{tabular}{cr}
\hline \hline \multicolumn{2}{c}{ Long-run results } \\
\hline \hline CONV_INDEX_SA(-1) & 1.000000 \\
& $0.615295^{*}$ \\
FDI(-1) & {$[0.06270)$} \\
& {$[9.81392]$} \\
& $0.248118^{*}$ \\
@TREND(00Q1) & $(0.02126)$
\end{tabular}


Adriana Anamaria Davidescu, Liviu Stelian Begu, Simona Andreea Apostu

\begin{tabular}{|c|c|c|}
\hline \multicolumn{3}{|c|}{$[-11.6698]$} \\
\hline $\mathrm{C}$ & -55.16114 & \\
\hline & Short-run results & \\
\hline & D(CONV_INDEX_SA) & $\mathrm{D}(\mathrm{FDI})$ \\
\hline$E C T_{t-1}^{1}$ & $\begin{array}{c}-0.154975^{*} \\
(0.05201) \\
{[-2.97991]}\end{array}$ & $\begin{array}{c}1.318988 * \\
(0.40828) \\
{[3.23057]}\end{array}$ \\
\hline $\begin{array}{c}\mathrm{D}(\mathrm{CONV} \text {-INDEX_SA(- } \\
1)\end{array}$ & $\begin{array}{c}0.407789^{*} \\
(0.13966) \\
{[2.91991]}\end{array}$ & $\begin{array}{c}0.880919 \\
(1.09640) \\
{[0.80346]}\end{array}$ \\
\hline $\mathrm{D}(\mathrm{CONV}=\underset{2))}{\mathrm{2})})$ & $\begin{array}{c}0.368327 * \\
(0.14705) \\
{[2.50476]}\end{array}$ & $\begin{array}{c}0.987260 \\
(1.15444) \\
{[0.85519]}\end{array}$ \\
\hline D(CONV_INDEX_SA(- & $\begin{array}{r}0.050129 \\
(0.14482) \\
{[-0.34615]}\end{array}$ & $\begin{array}{c}-0.429830 \\
(1.13691) \\
{[-0.37807]}\end{array}$ \\
\hline $\mathrm{D}(\mathrm{FDI}(-1))$ & $\begin{array}{r}0.081311 * \\
(0.03005) \\
{[-2.70599]}\end{array}$ & $\begin{array}{c}0.184361 \\
(0.23590) \\
{[0.78153]}\end{array}$ \\
\hline $\mathrm{D}(\mathrm{FDI}(-2))$ & $\begin{array}{r}0.064402 * \\
(0.02416) \\
{[-2.66543]}\end{array}$ & $\begin{array}{c}-0.029790 \\
(0.18969) \\
{[-0.15705]}\end{array}$ \\
\hline $\mathrm{D}(\mathrm{FDI}(-3))$ & $\begin{array}{c}0.035990 \\
(0.02013) \\
{[-1.78813]}\end{array}$ & $\begin{array}{c}0.250275 \\
(0.15801) \\
{[1.58393]}\end{array}$ \\
\hline $\mathrm{C}$ & $\begin{array}{c}0.053068 \\
(0.07882) \\
{[0.67331]}\end{array}$ & $\begin{array}{c}-0.291319 \\
(0.61876) \\
{[-0.47081]}\end{array}$ \\
\hline
\end{tabular}

${ }^{1}$ The error correction term must be negative and statistically significant in terms of $t$-test. 
Could FDI Inflows Be Considered a Driver of the Romanian Economic Convergence to European Union Average? A Granger Causality Analysis

\begin{tabular}{lcc}
\hline \hline R-squared & 0.441067 & 0.441338 \\
Adj. R-squared & 0.347912 & 0.348228 \\
Sum sq. resids & 10.82790 & 667.3460 \\
S.E. equation & 0.507747 & 3.986125 \\
F-statistic & 4.734740 & 4.739955 \\
Log likelihood & -32.69950 & -135.7291 \\
Akaike AIC & 1.627980 & 5.749163 \\
Schwarz SC & 1.933904 & 6.055086 \\
Mean dependent & 0.207315 & 0.008006 \\
S.D. dependent & 0.628773 & 4.937454 \\
\end{tabular}

$$
\begin{gathered}
\text { Autocorrelation LM test } \\
1.43 \\
{[n \times 31} \\
\text { Heteroskedasticity White Test } \\
88.89 \\
{[0.87]} \\
\text { Jarque-Bera Normality Test } \\
13.17 \\
\text { [n } n 11
\end{gathered}
$$

\footnotetext{
Note: Both series used in the models are I (1). The models we estimated assume one cointegrating equation. $\bar{R}^{2}$ is the coefficient of multiple determinations adjusted for the degrees of freedom (d.f). LM test is the Lagrange multiplier test of residual serial correlation at lag order 8 following $\chi^{2}$ distribution with $\mathrm{n}$ d.f, Normality test is based on a test of skewness and kurtosis of residuals, following $\chi^{2}$ distribution with $\mathrm{n}$ d.f and White test is a heteroscedasticity test, following $\chi^{2}$ distribution. Standard errors are in parentheses. S.E. is the standard error of the equation. [ ] denote the prob. levels. $*, * *, * * *$ indicates significance at the $1 \%, 5 \%, 10 \%$ levels.
}

The long-run coefficient of foreign direct investment is positive and strongly significant inferring that a $1 \%$ increase of FDI flows would imply an estimated increase of over $0.61 \%$ of the economic convergence index of Romania related to the EU-average on long-term. Therefore, it is safe to mention that the inflows of FDI were one of the factors contributing to the Romania's economic convergence towards the EU average.

The error correction term (ECT) for the convergence index has a value of -0.15 [-2.97] which implies that the deviation from the long-term equilibrium is corrected by $15 \%$ over each quarter, and therefore the convergence index 
Adriana Anamaria Davidescu, Liviu Stelian Begu, Simona Andreea Apostu

converges to its long run level due to the contribution of FDI flows with a $15 \%$ speed of adjustment. The lagged error term $\left(E C T_{t-1}\right)$ in our results is negative and highly significant suggesting therefore the presence of causality in at least one direction.

Regarding the inverse relationship, which might highlight a the potential causality relationship between the Romanian convergence towards EU-average and the inflows of FDI, the positive sign of the error correction term toghether with its statistical significance do not support a potential causality relationship running from the convergence index towards the FDI flows in the long-run.

All the coefficients of the short-run equation are coefficients relating to the short run dynamics of the model's convergence to equilibrium and the coefficient of the lag CV (error correction term) represents the speed of adjustment. The shortrun coefficients for the convergence index are positive and strongly significant, revealing that the lagged FDI inflows have a strong effect on the size of convergence index of Romania related to EU average in the short-run. Most of the lagged changes in convergence index and FDI flows are statistically significant. The short-run coefficients for FDI flows are not statistically significant pointing out the lack of short-run causality running from convergence level to FDI flows.

The results of VECM support that FDI flows explain little over $44 \%$ of the variation of the convergence index. The value of F-statistic provides evidences showing that the models are well specified. Important to mention is that the residual related hypothesis were verified using LM, White and JB tests. The empirical results point out the fact that VECM residuals are non-auto-correlated, homoskedastic but not normally distributed.

In the table 2 we report the F-statistics and also the t-statistics for the error correction term defined for the null hypothesis of no-causality.

Table 2. The empirical results of Granger causality

\begin{tabular}{|c|c|c|c|}
\hline \multirow[b]{2}{*}{ Null hypothesis } & \multicolumn{2}{|c|}{ Lag level 3} & \multirow[b]{2}{*}{ Results } \\
\hline & $\begin{array}{l}\text { Wald } \\
\text { test }\end{array}$ & $\overline{t_{E C T_{t-1}}}$ & \\
\hline $\begin{array}{l}\text { FDI/GDP does not } \\
\text { Granger } \\
\text { Convergence index }\end{array}$ & $8.28 * *$ & $-0.15^{*}$ & $\begin{array}{l}\text { Reject null } \\
\text { hypothesis=>FDI/GDP } \\
\text { Granger cause } \\
\text { Convergence index both on } \\
\text { long-run and on short-run. }\end{array}$ \\
\hline $\begin{array}{l}\text { Convergence index does } \\
\text { not Granger cause } \\
\text { FDI/GDP }\end{array}$ & 2.33 & 1.31 & $\begin{array}{l}\text { Accept null hypothesis=> } \\
\text { Convergence index does } \\
\text { not Granger cause }\end{array}$ \\
\hline
\end{tabular}


Could FDI Inflows Be Considered a Driver of the Romanian Economic Convergence to European Union Average? A Granger Causality Analysis

\begin{tabular}{l||l}
\hline & FDI/GDP \\
\hline \hline Notes: ** and * denote significance for 1\% and 5\% levels. Given the small size of our series \\
we used the lag length selected according Akaike criterion (3lags) running the tests. Using the \\
results of Pantula's principle, we selected the model 4 with intercept as optimal model for the \\
deterministic components in the system.
\end{tabular}

Therefore, we can state that we have a short-run causality running from FDI flows towards the convergence index to the EU-average (t-ratio of ECT and Wald test for short-run coefficients are statistically significant at $1 \%$ and $5 \%$ levels, and the ECT is negative). Summarizing the empirical results we have both long-run and short-run causality that runs from FDI inflows to the convergence index of Romania to the EU-average, since the lagged coefficients are jointly significant in terms of Wald statistics and also, the error correction term has a negative value and is statistically significant.

The null hypothesis of no-causality is accepted for the relationship running from the convergence index towards the FDI flows, given the lack of significance of the Wald statistics for the short-run coefficients and also of the t-test for the error correction term for long-run.

Concluding, we can assert that, the Granger causality results revealed the existence of both long-run and short-run unidirectional causality that runs from the FDI inflows to the Romanian convergence index to the EU-average. Therefore, it becomes obvious that foreign capital is one of the tools that can be leveraged by the Romanian authorities in order to increase the economic development level of the country and to accelerate the convergence process. Thus, it is advisable to construct both, policies destined for supporting the local capital and policies supporting the foreign capital, without diminishing the attention for one of them to the favour of the other.

In order to quantify the effects of a shock in the FDI/GDP inflows on the convergence index we will apply the generalized impulse response functions 2(GIRFs) proposed by Pesaran and Shin (1998).

In Figure 2 the impulse responses of the convergence index to the shocks in the FDI inflows are described. The results suggest that the convergence index increased continuously from the initial shock in FDI inflows. Thereby, it is visible that in the 8th quarter it reached its saturation potential with an increase of about $1 \%$, maintained over the last three quarters.

\footnotetext{
${ }^{2}$ An application of IRF is provided by Ito, K." Oil process and Russian Economy: A VEC model Approach", International Research Journal of Finance and Economics, ISSN 1450 2887 Issue 17 (2008).
} 
Adriana Anamaria Davidescu, Liviu Stelian Begu, Simona Andreea Apostu

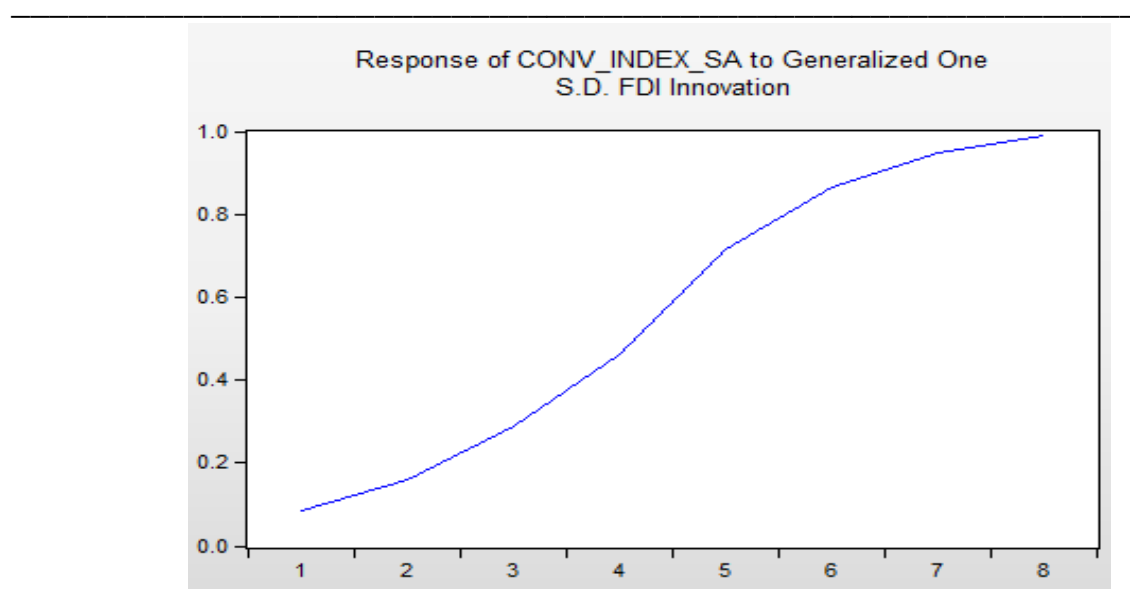

Note: (1) Sample periods are from 2000:Q1 to 2013:Q2 with 3 lags and one restricted co-integrating vector. (2) Impulse responses for up to 8 quarters are displayed.

Figure 2. Generalized impulse response functions (GIRFs) for the VEC Model

In order to calculate the percentage of variation of the Romanian convergence index towards the EU-average that can be attributed to its own shock and to the shocks in the FDI inflows we will use the variance decomposition.

The empirical results revealed that a substantial portion of the variance of the convergence index (98\%) is explained by its own innovations (or shocks) in the short-run (at 3-quarters horizon) and by only a small portion (2\%) by the shocks in the FDI. In the long run (10 quarters horizon); shocks in the foreign direct investment explain about $30 \%$, of the shocks registered in the convergence index.

Table 3. Variance Decomposition of convergence index

\begin{tabular}{cccc}
\hline \hline Period & S.E. & CONV_INDEX_SA & FDI \\
\hline \hline 1 & 0.507747 & 100.0000 & 0.000000 \\
2 & 0.822937 & 99.54958 & 0.450416 \\
3 & 1.171134 & 97.99700 & 2.003003 \\
4 & 1.486496 & 93.89746 & 6.102540 \\
5 & 1.836579 & 86.14764 & 13.85236 \\
6 & 2.190820 & 79.46381 & 20.53619 \\
7 & 2.538962 & 74.97292 & 25.02708 \\
8 & 2.869851 & 72.08679 & 27.91321 \\
9 & 3.176014 & 70.51587 & 29.48413 \\
10 & 3.460014 & 69.55350 & 30.44650 \\
\hline \hline
\end{tabular}

Cholesky Ordering: CONV_INDEX_SA FDI 
Could FDI Inflows Be Considered a Driver of the Romanian Economic Convergence to European Union Average? A Granger Causality Analysis

Therefore, we have proved the existence of a positive causality both on shortrun and also on the long-run that runs from the flows of FDI received by Romania towards its convergence index to the EU-average.

Based on these findings, it becomes obvious that the policy makers need to pay special attention to the foreign direct investments sector due to the fact that it might be an important tool to fuel Romania's development and to catalyze its convergence towards the European Union's average. Therefore, shaping policies with the clear purpose of attracting foreign investors needs to be regarded, both at national and at regional level, as a major priority.

Following the same direction, of an increased importance should be the development of specific policies which will improve the capacity of the Romanian economy to internalize the benefits brought by the foreign direct investments and to increase in this way its convergence speed. Even though there are some voices, among the scholars interested in the subject of foreign direct investment, who argue that some foreign direct investments received by developing countries are not improving the economic convergence capacity of their economies, the findings of this study show a clear causal relation for the case of Romania. Thus, an analysis which will identify the type of investments which bring the most important benefits and have the greatest impact on the economic convergence, for the case of Romania, should be regarded as a further research direction both by scholars and by representatives of the authorities.

\section{Conclusions}

The main objective of the paper is to investigate the causality relationship between the FDI inflows, expressed as \% of the official GDP, and the Romanian convergence index towards the EU-average, using Granger causality tests. More precisely, using multivariate co integration and error correction model (VECM), we examine the impact of the inflows of foreign direct investments on the Romanian convergence index, covering the period 2000-2013, on the basis of quarterly data.

The most important result that was obtained indicates that there exists both a positive long-run and short-run relationship between the inflows of FDI and the convergence index. Therefore, it is safe to argue that there is a unidirectional shortrun and long-run Granger causality running only from the inflows of FDI towards the convergence index. In the long-run, a $1 \%$ increase of the inflows of FDI would imply an estimated increase of little over $0.61 \%$ in the economic convergence index of Romania towards the EU-average.

The impulse responses function and the variance decomposition from VECM indicate a short-run positive relationship between FDI inflows and the economic convergence index. The analysis leads to the finding that, on the short-run, a $1 \%$ increase in FDI/GDP contributes to an increase in the convergence index towards the EU-average of $1 \%$ over the next eight quarters. Due to the fact that this index 
Adriana Anamaria Davidescu, Liviu Stelian Begu, Simona Andreea Apostu

expresses the distance against the EU average, a $1 \%$ increase of the index indicates that the convergence to the European average is increasing.

Therefore the Romanian policymakers should pay special attention to the subject of foreign direct investments due to the fact that they are one of the tools that Romania can use in order to increase its convergence speed towards the EU average. Thus, shaping policies with the purpose of increasing Romania's attractiveness for foreign investors should be considered a major priority at the level of the Romanian authorities. Moreover, nowadays when the public space is filled with controversies regarding the competition between foreign and local capital the authorities do not need to fall in the trap of supporting one of them by diminishing the attention for the other. Also, in the current situation when nationalism movements are growing all around Europe, supporting the FDI should be seen by national authorities as an important tool for constructing bridges between nations. Thereby, by supporting the construction of such bridges, the authorities would give the possibility for good practice models, technological development and human capital to spread easily all around across Europe and diminish therefore the economic (and standard of living) disparities at the level of the Union.

Moreover, in these conditions, it would be of great interest for further research to identify the typology of the foreign direct investment (and also the economic field where investments are made), which brings the greatest benefits in Romania having therefore an increased impact on the economic convergence speed.

\section{REFERENCES}

[1]Alexandru (Davidescu), A., Dobre, I. (2013), The Impact of Unemployment Rate on the Size of Romanian Shadow Economy; Public Finance Review, Special Issue:

The Shadow Economy, Tax Evasion, and Money Laundering, September 2013 41: 608632, first published on June 16, doi: 10.1177/1091142113487006;

[2] Alexandru (Davidescu), A., Dobre, I. (2012), The Causal Relationship between Unemployment Rate and U.S. Shadow Economy. A Toda-Yamamoto Approach; Journal of Social and Economic Statistics, no.1/2012, pg.21-34, ISSN 2285-388X;

[3] Alexe, I., Tatomir, C. F. (2011), Does Economic Convergence with the EU Mean More FDI Flows to an Economy? Analysis on 5 Central and Eastern Europe Countries; MPRA Paper No. 36139, Online at http://mpra.ub.unimuenchen.de/36139/;

[4] Bajo-Rubio, O., Sosvilla-Rivero S. (1994), An Econometric Analysis of Foreign Direct Investment in Spain, 1964-1989. Southern Economic Journal, 61: 104-120;

[5] Balasubramanyam, V. N., Salishu M., Sapsford, D. (1996), Foreign Direct Investment and Growth: New Hypotheses and Evidence. Discussion Paper Ec: 7-96, Dept. Of Economics, Lancaster University;

[6] Barrios, S., Barry, F., Strobl, E. (2002), FDI and Structural Convergence in the EU Periphery; Centre for European Policy Research, Workshop and Conferences no. 2319; 
Could FDI Inflows Be Considered a Driver of the Romanian Economic Convergence to European Union Average? A Granger Causality Analysis

[7] Basu, P., Chakraborty, Ch., Reagle, D. (2003), Liberalization, FDI and Growth in Developing Countries: A Panel Cointegration Approach; Economic Inquiry, 41(3), pp 510-516;

[8] Borensztein E., de Gregorio J., Lee J. (1998), How Does Foreign Direct Investment Affect Growth; NBER Working Paper no 5057 (Cambridge, M.A: NBER);

[9] Buckley P.J., Clegg J., Wang, C., Cross, A.R. (2002), FDI, Regional Differences and Economic Growth: Panel Data Evidence from China; Transnational Corporations, 11, 1, pp1-28;

[10] Choi, C.(2004), Foreign Direct Investment and Income Convergence; Applied Economics, Vol. 36, Issue 10, 1045-1049;

[11] Culem, C.G. (1988), The Locational Determinants of Direct Investment among Industrialized Countries; European Economic Review, 32, 885-904;

[12] De Mello, L.R., Jr. (1997), Foreign Direct Investment in Developing Countries and Growth: A Selective Survey; The Journal of Development Studies, 34, pp 1-34;

[13] Díaz Vázquez, R., Novoa García S., Outes Ruso X.L.(1996), Foreign

Investment in Spain; document elaborated for the project "Structural Competitiveness in four European countries. Macroeconomic, sectoral and regional aspects" by the CEE (ERBCHXCT 930223);

[14] Diaz Vazquez, R. (2004), Foreign Direct Investment and Regional Convergence: An International Approach; ERSA conference papers, European Regional Science Association;

[15] Frankel, J.A., Rose, A.K. (1998), The Endogenity of the Optimum Currency Area Criteria; The Economic Journal, Vol. 108, 1009-1025;

[16] Galor, O. (1996), Convergence? Inferences from Theoretical Models; The Economic Journal, Vol. 106, No. 437, 1056-1069;

[17] Goldberg, M.A. (1972), The Determinants of US Direct Investment in the EEC: Comment; American Economic Review, 62: 692-9;

[18] Johnson H.G. (1973), Survey of the Issues; in Peter Drysdale (ed.), Direct Foreign Investment in Asia and Pacific, Toronto: University of Toronto Press, 1-17;

[19] Krugman, P. (1991), Geography and Trade; MIT Press, Cambridge;

[20] Miron, D., Dima, A., Păun, C. (2009), A Model for Assessing Romania's Real Convergence Based on Distances and Clusters Method; Munich Personal RePEc Archive MPRA, paper no. 31410;

[21] Onen, E. (2008), Foreign Direct Investment and Business Cycles, An Empirical Analysis of United States; United Kingdom, Turkey, Euro-area and China, Master Thesis, ID number: i468762, Maastricht University;

[22] Root, F.R., Ahmed, A.A. (1979), Empirical Determinants of Manufacturing Direct Foreign Investment in Developing Countries; Economic Development and Cultural Change, 27 (1979)751-767;

[23] Schneider, F., Frey, B. S. (1985), Economic and Political Determinants of Foreign Direct Investment. World Development, 13, 161-175; 
Adriana Anamaria Davidescu, Liviu Stelian Begu, Simona Andreea Apostu

[24] Strat, V. A.(2014), What Happened with the Attractiveness of the Romanian Counties for FDI during the Period 2001 - 2012? Journal of Applied Quantitative Methods, Vol. 9, No. 4, Decembrie 30, ISSN 1842-4562;

[25] Strat, V. A., Popovici, O. C. (2015), FDI Convergence versus Real and Structural Convergence at the EU Level. An Approach Based on the GINI Coefficient; Economia. Seria Management, Vol 18, Issue 1, pp 150 - 162, ISSN 23444436;

[26] Davidescu, A.A.M, Strat, V.A., Grosu, R.M. and Zgură, I.D.(2017), Determinants of Romanians' Migration within the European Union: Static and Dynamic Panel Gravity Approaches. Amfiteatru Economic, 19(46), pp. 621-639; [27] Van de Coevering, C. (2003), Structural Convergence and Monetary Integration in Europe; Bank of Netherlands, Monetary and Economic Policy Department, MEB Series nr. 2003-20;

[28] Viasu I. (2015), The Long-term Causality. A Comparative Study for some EU Countries; Computational Methods in Social Sciences (CMSS), Vol 3, Issue 2, pp.2835 ;

[29] Vijaykumar, N. P. S., Rao, K. C. S. (2010), Determinants of FDI in BRICS Countries: A panel analysis. International, Journal of Business Science and Applied Management, 5, 1-13;

[30] Wei, S. (1995), Foreign Direct Investment in China: Sources and Consequences, in Ito Terutomoto and Anne O. Krueger (Eds), Financial Deregulation and Integration en East Asia (Chicago: University of Chicago Press) pp.77-101;

[31] *** https://www.imf.org/external/pubs/ft/bopman/bopman.pdf, last accessed 05.06.2018;

[32] *** Internal Financial Statistics (IFS) Database, International Monetary Fund, last accessed 05.06.2018;

[33] *** Quarterly National Accounts database-Eurostat, last accessed 05.06.2018;

[34] *** Quarterly Employment and Unemployment (Labour Force Survey), Eurostat, last accessed 05.06.2018;

[35] *** International trade quarterly database, Eurostat, last accessed 05.06.2018;

[36] *** Quarterly Average Exchange rates-Eurostat, last accessed 05.06.2018. 